\title{
Honor and Authority Redefined in Luke 22:24-30
}

\author{
Yang Yan \\ Sun Yat-sen University, Guangzhou
}

\begin{abstract}

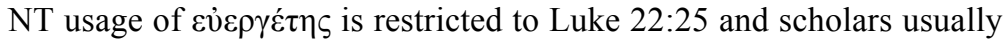
employ the interpretation of "benefactor" to understand Luke 22:24-30. However, the verbal, conceptual or structural evidence is far from enough to support such interpretation. Instead, the whole episode focuses on the idea of the greatest. With the kings and benefactors as conventional models in political and civil sphere respectively, the Lukan Jesus renounces recognition of the greatest on the basis of superior status and exercise of authority. By the sharp contrast between the reclining and serving in the banquet setting, Jesus proposes a totally new definition of the greatest. That is, the lower status and humble or even humiliating service (loyalty to Jesus) are the markers of the greatest and conditions to be the greatest. The greatest do have honor and authority, but both of them are hidden on earth and will be manifest in future in heaven.
\end{abstract}

Keywords: benefactor, honor, authority, servanthood, greatness

\section{Introduction}

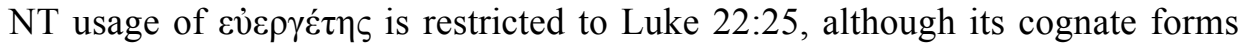

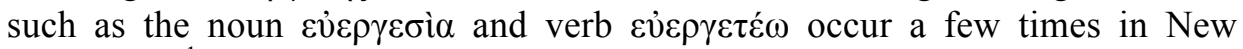
Testament. ${ }^{1}$ Scholars usually employ "benefactor" interpretation to understand Luke 22:24-30. Generally, there are mainly two trends in interpretations on Luke 22:24-30: ${ }^{2}$ The Lukan Jesus proposed the main criteria for a true benefactor or an ideal king, with himself as the benefactor par excellence on the

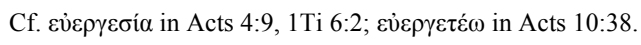

2 There are also disputes over the sources of this episode, whether it is from Mark, Matthew or Q or Luke's special source. Since this issue is not significant for our discussion here, we will not address it in this paper.

William Loader, Boris Repschinski, Eric Wong (Eds.)

Matthew, Paul, and Others: Asian Perspectives on New Testament Themes

(C) 2019 innsbruck university press, ISBN 978-3-903187-66-5, DOI 10.15203/3187-66-5 
one hand and on the other hand Herod or Gentile kings as a bad model (Danker, 1988; Seo, 2015; Nelson, 1994; Marshall, 2009); ${ }^{3}$ or the Lukan Jesus criticized both inequality and reciprocity of the Roman benefaction or patron-client system (Deissmann, 1927; Ahn, 2006). Considering the immediate context (Luke 22:24 and 22:26-30), we propose that the focus of this episode is neither the benefactor model nor the patron-client system but the overturning of the honor-authority as markers of the greatest in Roman society (Nelson, 1994). ${ }^{4}$ Benefactors as the social model of the greatest are renounced because of their pursuit of honor from their recipients and because of their exercise of authority. Jesus redefines the honor and authority of true greatness, which is given though hidden in the present age but will be manifested in the future age.

\section{The Conventional Idea about the Greatest (v 25)}

The whole episode is evoked by the dispute among the disciples about which of them was to be regarded as the greatest. As stated by Nelson, the issue here is not who wants to be greatest (Markan version), or is greatest, but who seems to

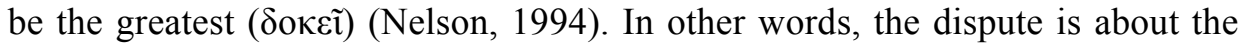
conventional definition of the greatest. Jesus cites the normal opinion on it in $\mathrm{V}$ 25. Jesus said: "The kings of the Gentiles lord it over them; and those who have authority over them are called 'Benefactors'."(NAS). Most scholars claim that these two sentences/titles refer to the same group of people, that is, "king" is a synonym for "benefactor" (Seo, 2015; Marshall, 2009; Nelson, 1994). ${ }^{5}$ It is true that Augustus is willing to be called benefactor (Nicols, 1990), and Vespasian was hailed as "Benefactor and Savior" by the crowd (Josephus, J.W. 7.4.1), at

3 Seo (2015) argues that the pagan kings are not eligible to be called true benefactors, since true benefaction is service-oriented. Although the opinion proposed by Nelson (1994) that Jesus is the model of a leader and demonstrates the relationship between service and leadership is different to some extent, the key point is similar, that is, Jesus sets an example.

$4 \quad$ Nelson (1994) notices the authority theme but relates the authority (v 25b) to the leadership and then argues that leadership and discipleship are concepts central to this episode. Nelson examines mostly every word in detail, but does not demonstrate his theme (leadership and discipleship) fully and explain how the authority extends to leadership.

5 Seo (2015) argues that first-century people would have thought of the emperor in association with the title "benefactor" when they listened to/heard Jesus' teaching in Luke 22:25. Marshall (2009) proposes that "them" in

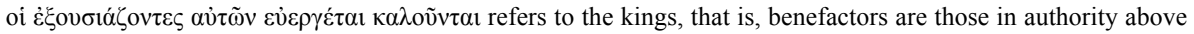
the kings. This opinion receives little support.

William Loader, Boris Repschinski, Eric Wong (Eds.)

Matthew, Paul, and Others: Asian Perspectives on New Testament Themes

(C) 2019 innsbruck university press, ISBN 978-3-903187-66-5, DOI 10.15203/3187-66-5 
the same time, that kings usually have the authority. However, considering the following two factors, we propose that these two titles in Luke 22:25 are not tautological but refer to two different groups of people, with overlapping in some cases. Firstly, from the perspective of the sentence structure, "oi $\ddot{\alpha} \rho \chi 0 v \tau \varepsilon \varsigma$

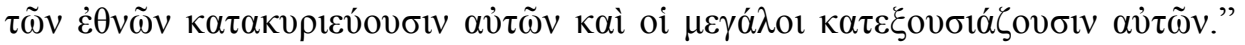

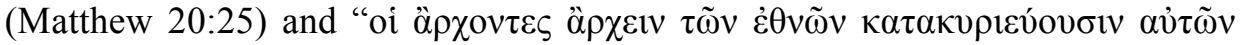

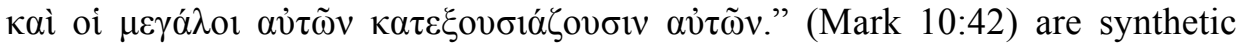
parallelism, with basic nominative masculine plural + present indicative active $3^{\text {rd }}$ personal plural, while Luke 22:25 does not have such strong synthetic parallelism, and therefore is not bound to refer to one group of people. ${ }^{6}$ Secondly, both subjects in the Gospels of Matthew and Mark are the ruling or

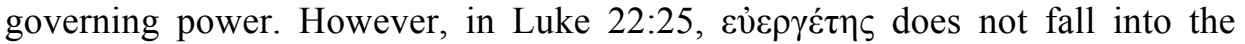

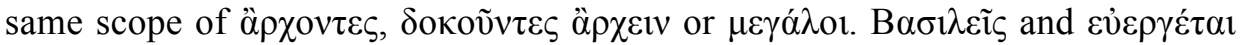
fall into the political and civil realm respectively. Benefaction, as a voluntary and reciprocal relationship between the people of the unequal status, prevailed in the Eastern Roman particularly (Eilers, 2002; Saller, 1982; de Silva, 2000;

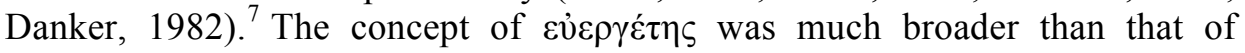

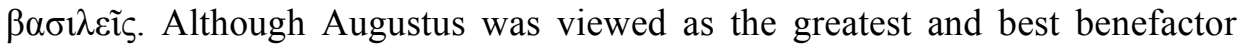
during the principate (Danker, 1982, No. 31,32,39), and tyrants would like to call themselves the benefactors (Danker, 1982, pp. 42-44), "benefactor" is not confined to the official post of a ruler, but applied widely in society. Therefore, the Lukan Jesus probably listed representatives in the political and civil sphere respectively to illustrate the normal understanding of the greatest, which he negates.

We turn to two examples. It is normal that the kings both are and are regarded as the greatest in their territories. As stated in $v 25 \mathrm{a}$, it is the ruling power that entitles kings to be considered the greatest. In other words, kings' greatness is presented and grounded in their exercise of the lordship. The life of Pompey, the famous general and consul of the Roman Republic, demonstrates

6 Whether Luke and Mark shared a similar tradition, or Luke depended on Mark, or Luke derived from Matthew will not be discussed here, since we focus on the intention of Luke.

7 Several scholars debate the difference between patronage and benefaction. Marshall (2009) argues that the western Roman Empire preferred the title $\pi \alpha \dot{\tau} \rho \omega v$. Joubert (2000) and Marshall (2009) distinguish patronage from benefaction, while Crook (2012) holds them more closely together. Similarly, scholars apply the concepts of patronage or benefaction to the interpretation of Luke 22:24-30. We will not discuss the difference between the Hellenistic system of benefaction and Roman patrocinium, and their relevance to Luke 22:24-30 here since both systems imply an between the concerned parties.

William Loader, Boris Repschinski, Eric Wong (Eds.)

Matthew, Paul, and Others: Asian Perspectives on New Testament Themes

(C) 2019 innsbruck university press, ISBN 978-3-903187-66-5, DOI 10.15203/3187-66-5 
this point. Pompey was initiated called Magnus (the Great) by his loyal troops in Africa (82-81 BCE), and he assumed the cognomen Magnus after 81 (Plutarch, Pompey, 13; Pliny, NH 7.97; Southern, 2002; Seager, 2002). ${ }^{8}$

Differently, the benefactor is usually not the greatest in the community or, to be more precise, his greatness is not like the greatness of the kings whose ruling power dominates every aspect of life in the ancient world. The epigraphs honoring the benefactors show the diversity of who were considered benefactors: physicians, fighters, flamen, priest, officials of various ranks (Danker, 1982, No. 1-3, 6, 11-12, 15-18, 20-21). How is being benefactors relevant to being the greatest? Taken as meaning "competition for the honor" (Marshall, 2009, p. 303), pıtoveıкía in v24 indicates that the issue of being the greatest is about honor-shame in the ancient world. Honor could be gained or lost (Esler, 1995, p. 185). The critique from Aristotle of benefactors as lovers of honor (Rhet. 1361a43-1361b3) verifies that benefactors pursued honor (van Wees, 1998). The benefactor seeks to be recognized publicly in various ways, such as the incised name on stone, the awarding of a gold crown, or the gift of a permanent seat of honor in the theater. ${ }^{9}$ Honor is usually one's claim of one's own worth, pride, but also the acknowledgement and recognition of the validity of that claim by society (Pitt-Rivers, 1977, p. 1). Just like $\delta$ окєі, the passive voice $\kappa \alpha \lambda$ ovv $\tau \alpha$ implies the benefactor's pursuit to be recognized by the

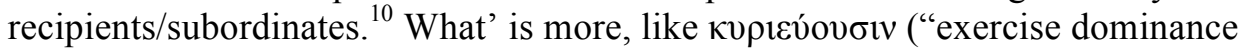

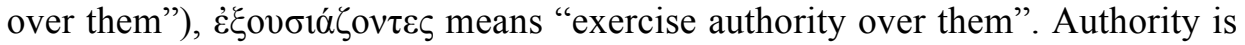
regarded as the explicit capacity to direct others' behaviors (Hoebel, 1985, p. 222). According to the inscriptions listed by Danker, the benefactors alleviate the tax burdens, forgive the debts, distribute money or hold a medical profession

\footnotetext{
During that time, Pompey began to taste kingly power which does not seem to have been challenged.

From thousands of inscriptions, we see no challenge to the honor-seeking of the benefactors. The ancient writers seldom doubted this pursuit. For example, Gnaeus Arrius Cornelius Proculus wrote to the Lycian League: "Generous people are deserving of honor." (Danker, 1982, No. 19.8.29.11-14). What concerned them most was whether the benefactors showed enough generosity worthy of their titles (Dio Chrysostom, Oratio 46, 31, 44; Seneca, de Beneficiis I.xv.6), or the beneficiaries expressed appropriate gratitude (Dio Chrysostom, Oratio 40.78; Seneca, de Beneficiis I.iv.4-5, I.x.4). However, these discussions refer only to the decline in the giving of appropriate honor or exaltation of oneself associated with the arrogance of power, but none of them refers to a behavior or ways of benefitting others without receiving or seeking honor (Seneca, de Beneficiis I.xv.2; Danker, 1982, No. 43).

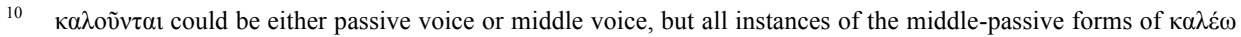
in Luke-Acts connected to personal nouns are passive (Nelson, 1994, p. 153).
}

William Loader, Boris Repschinski, Eric Wong (Eds.)

Matthew, Paul, and Others: Asian Perspectives on New Testament Themes

(C) 2019 innsbruck university press, ISBN 978-3-903187-66-5, DOI 10.15203/3187-66-5 
(Danker, 1982, No. 1, 2, 4, 31.). No matter which benefaction is given, the benefactors enjoy the prestige and accordingly, the recipients are obligated to do certain things in return. The influence of the benefactors brings an implicit power into play (compared with the explicit power of governance) and so is associated with authority. The honor and authority or power over the recipients in a particular realm makes them look like the greatest (Joubert, 2002). ${ }^{11}$

In a word, with two examples in the political and civil realm, vv 24-25 reflecthe typical thinking in the Mediterranean world about what it means to be the greatest: the greatest are those who enjoy and acquire honor, and who have mastery over or exercise dominant power over the others.

\section{The Correction of the Traditional Idea of the Greatest (vV 26-27)}

Lull (1986) states that $\mathrm{v} 26 \mathrm{a}$ is to be interpreted as "but you are not [called] thus [namely, benefactors]". It is partly right. 'Y $\mu \varepsilon i \tilde{\varsigma}$ and $\dot{\varepsilon} v$ v $\mu \tilde{v} v$ indicate that the audience of Jesus' discourse are the disciples. Since there is no relevant connection between the disciples and kings with regard to status, the prohibition being applied to them is not about being kings but about beingbenefactors. We

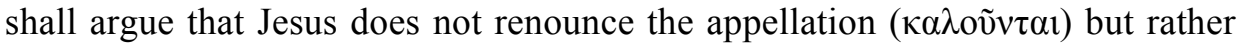
the pursuit of honor and understanding of the greatest from the perspective of the dominant power.

Compared with Matthew 20.26b-27 and Mark 10.43b-45, Luke 22.26b has two different points. Firstly, the former two use the subjunctive mood to exhort those who wish to be great and first. With strict parallelism, they claim what behavior determines who is the greatest. In the Lukan version, however, Jesus uses the imperative mood. That is, Jesus admits the greater status of some disciples and thus portrays the possession of greatness positively. In other words, Jesus does not intend to eliminate them. But the emphasis is on how the greatest among disciples should be (Schürmann, 1957; Lull, 1986; Moxnes, 1991).

11 It is well known that the key characteristic of benefaction is "generosity and gratitude", with the benefactor showing generosity, and the recipients in turn expressing gratitude by various actions. The reason why $\mathrm{v} 25 \mathrm{~b}$ does not mention "generosity and gratitude" is probably because it is an independent of the issues of greatness.

William Loader, Boris Repschinski, Eric Wong (Eds.)

Matthew, Paul, and Others: Asian Perspectives on New Testament Themes

(C) 2019 innsbruck university press, ISBN 978-3-903187-66-5, DOI 10.15203/3187-66-5 
Secondly, in the Matthean and Marcan version, Jesus contrasts "great" with "servant", and "first" with "slave". Differently, Lukan Jesus contrasts "greater" with "younger", and "the one governing" with "the one serving". 12 The contrast between the greater and the younger also appears in Luke 9:46-48 (the greater Vs the little child). The youngest in the ancient world was usually regarded as the lowest, having the lowest position in society. For example, in the ancient Near East, the children/youngest were usually held in very low regard (1QM7.3; Gundry, 1982; Jeremias, 1963; Hendricksen, 1978; Morris, 1988.). At the same time, the youngest are away from authority. In Roman society, Roman cursus honorum regulates age qualification, that is, the young elites may be too young to be appointed as public officials. For example, when Scipio Africanus or Augustus thrusted into the public's eye for the first time, they were regarded as unspectacular since they are quite young. Similarly, the

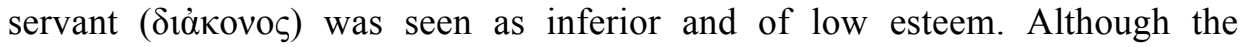
benefactor usually offers generous/philanthropic service such as building public temples, theaters, aqueducts, forums, sponsoring the shows, spectacles and distributing bread or money (Res Gestae Divi Augustus 15-23; Danker, 1982, No. 8.), or meeting the various needs of people, such as physical healing, the right to hold property, security, citizenship and so on (Danker, 1982, No. 1$5,9,11,12,16,21,23,28)$, none of these services, which are full of honor, compares with the lowliness of the servanthood in $\mathrm{v} 26 \mathrm{~b} .{ }^{13}$ Though few benefactors pursue modesty or decline aggrandizement, none of them seeks lowliness (Danker, 1982, No. 19,43.). Besides, "the one governing" with its foil "the one serving" indicates the element of authority in the idea of the greatest. ${ }^{14}$

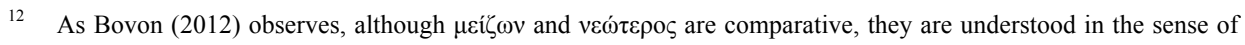
better or younger than others, and so are usually translated greatest of all and youngest of all (Nolland, 19891993, p. 1064; Fitzmyer, 1981-1985, p. 1416).

13 Seo (2015) argues that the Lukan Jesus emphasizes service as the basis of a true benefactor's greatness. However, service-oriented benefaction proposed by Seo is no different from altruistic general benefaction, which is claimed by certain Roman writers such as Dio Chrysostom (Oratio 4.65-66) or Cicero (Officiis, 1.44) or Seneca (Beneficiis, 4.7.1). And there is no textual evidence (in vv 24-30) to support the notion of general benefaction.

14 Some scholars propose that the term $\dot{\eta} \gamma o v ́ \mu \varepsilon v o \varsigma$ refers to church leaders, and $\delta 1 \alpha \kappa o v \tilde{\omega} v$ to church officers. For example, Nelson (1994) simply asserts that the misunderstanding of the nature of the authority in v 24 is to be replaced by a new and unconventional model of leadership, or that it is all about ruling as referring to church leadership. However, this correlation does not fit the immediate context and does not help us understand the episode as a whole. We tend to treat the terms as a general reference to those who have ruling powers and who serve humbly (Evans, 1990; Goulder, 1989; Loisy, 1924; Ernst, 1977; Horn, 1983). Some scholars relate the

William Loader, Boris Repschinski, Eric Wong (Eds.)

Matthew, Paul, and Others: Asian Perspectives on New Testament Themes

(C) 2019 innsbruck university press, ISBN 978-3-903187-66-5, DOI 10.15203/3187-66-5 
This contrast relates the greatness to the powerless servant, which is demonstrated more clearly in the following verse (v 27) (see more as below).

In summary of $\mathrm{v} 26$, Jesus cuts the normal relevance of high status, authority for understandings of greatness. The Lukan Jesus renounces the motive behind the dispute (the pursuit of honor) and claims not to view the greatest as the one with honor and authority (Marshall, 2009; Nock, 1972; Plummer, 1901; Winter, 1988).

V 27 is unique to the Gospel of Luke, in which Jesus restates the dispute in V

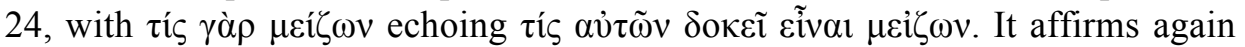
that the whole episode is about the understanding of the greatest. In v 27, Jesus takes the meal occasion to illustrate how he understands what it means to be the greatest. The practice of reclining ( $\alpha v \alpha \kappa \varepsilon i ́ \mu \varepsilon v o \varsigma, v 27)$ is virtually universal throughout the Greco-Roman as a marker for the formal banquet of significance (Smith, 2012; Roller, 2006). Especially the banquet, as dinstinct from a dinner, is a common occasion to convey one's status and a place to indicate hierarchical power in Roman society (Dunbabin, 1998; Daniel-Hughes, 2012). ${ }^{15}$ The status and power are negotiated through dining postures. The hierarchical principle is: the body that moves or takes action in response to others is inferior, while the stationary body that does not need respond to others' need is superior (cf. Luke 17.7-10). Accordingly, the reclining posture, which is originally aristocratic and then imitated by the lower social groups, is fundamentally a mark of superior status (Suetonius, Poet. fr. 11, 28-29; Roller, 2006; McRae, 2011; Klinghardt, 2012; Kloppenborg, 2016). ${ }^{16}$ Other postures are intentionally indicate lower status. For example, the servants, normally the slaves, areusually on their feet, either being busy with various tasks or awaiting orders from the diners (Seneca,

service here to Jesus' service such as footwashing, suffering, and crucifixion. However, there is no indication of this here before the correlation proposed by Jesus himself in v 27 (J. Bailey, 1963; Plummer, 1901; Nelson, 1994).

15 Wealthy members who funded banquets used them as vehicles to recognize, honor and confirm publicly hierarchical status in association, which is usually called benefaction. That is why Neyrey (1991) claims that the meal as a ceremony functioned to confirm roles and statuses within the chief institutions of a given group. Similar conditions also applied in patron-client relationship. Since the text does not indicate any specific relationship and the emphasis here is not benefactor-recipient or patron-client relationship but the contrast between different postures, we see no need to pursue what specific relationships might have been in mind here.

16 Reclining on the foremost couch or the least important couches is determined according to status. Similar norms, emphasizing seating arrangements (cf. Luke 14:7-11; 22:14; Mt. 22.10-11;26.7), also applied in the first-century Jewish world (Philo, Cont. 67).

William Loader, Boris Repschinski, Eric Wong (Eds.)

Matthew, Paul, and Others: Asian Perspectives on New Testament Themes

(C) 2019 innsbruck university press, ISBN 978-3-903187-66-5, DOI 10.15203/3187-66-5 
Ep. 47.3; Roller, 2006). In other words, the dining postures are corporeal acts marked with symbolic power. To lie down to eat and drink other than to stand or sit or move to serve is a sign of power, privilege and prestige (DanielHughes, 2012; Roller, 2006; Dunbabin, 2010; Donahue, 2015). ${ }^{17}$

With the ovi in the rhetorical question of $\mathrm{v} 27 \mathrm{~b}$, the Lukan Jesus expresses the conventional understanding of the great. That is, reclining at the table, with honor and power, is usually regarded as the greatest. ${ }^{18}$ With the pronoun $\dot{\varepsilon} \gamma \grave{\omega}$, Jesus gives a contrary stance. $\mathrm{O} \delta 1 \alpha \kappa o v \tilde{\nu} v$ in $\mathrm{v} 27 \mathrm{c}$ echoes directly the reference to those serving at the table in $\mathrm{v} 27 \mathrm{a}$. And more importantly, it may refer to the profound service in the work of salvation (suffering, crucifixion) which is full of humiliation (cf. Mark 10:45b, Passover context, see the following discussion about the disciples' service in v 28). ${ }^{19}$ Jesus is undoubtedly the greatest among the disciples but chooses to live humbly and even in shame. By serving the disciples, Jesus gives up high status as well as the exercise of power in public eyes. With himself as the model, Jesus substitutes lower and humble appearance for the traditional idea of the greatest.

In a word, given the repetitive expression of "among disciples", such as $\dot{\varepsilon} v$

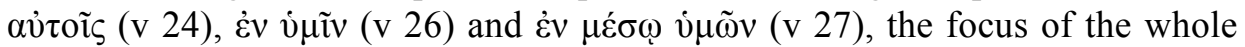
episode is disciples, neither beneficence, servanthood nor the patron-client system. ${ }^{20} \mathrm{Vv} 26-27$ follow the dispute in v 24 tightly. With the youngest and servant as the greatest, Jesus renounces the conventional equation of greatness with having honor and authority. And then using the occasion of the meal, the conventional context for demonstrating such understandings of greatness, he offers himself as a contrasting model, namely as a lowly and powerless servant. $^{21}$

17 Status is a reflection of one's power.

18 Roman writers wrote satires to transgress barriers and boundaries between diners and slaves (cf. Lucian, Dialogues of the Courtesans; Petronius, Satyricon), however, none of them swaps these two.

19 Its location in the passion narrative and the impending passion of Jesus implies an interpretation of Jesus' death as service (Nelson, 1994).

20 These viewpoints are: the Lukan Jesus challenges conventional asymmetrical patron-client relationships and articulates a new model of relationship among people. Or the Lukan Jesus proposes a "servant-benefactor" model. Marshall (2009) argues that the conferment of a kingdom is one of benefaction that benefactors may bestow upon a subordinate. It might be right in general, but shall not be applied here.

21 Ahn (2006) points to Jesus' death as an example of an alternative way of exercising authority without fully elaborating.

William Loader, Boris Repschinski, Eric Wong (Eds.)

Matthew, Paul, and Others: Asian Perspectives on New Testament Themes

(C) 2019 innsbruck university press, ISBN 978-3-903187-66-5, DOI 10.15203/3187-66-5 


\section{The Hidden Honor and Authority (vv 28-30)}

Vv 28-30 are not traditionally considered part of vv 24-27 (Schürmann, 1957; Marshall, 2009). In order to support the connection between vv 28-30 and the preceding verses, several scholars point to verbal, conceptual and structural evidence. For example, Lull notes the syntactical construction ( $\dot{\varepsilon} \gamma \hat{\omega} \delta \dot{\varepsilon}$, $\varepsilon \dot{\jmath} \mu 1$, $\left.\dot{v} \mu \varepsilon i \varsigma_{\zeta} \delta \varepsilon \dot{\varepsilon} \sigma \tau \varepsilon\right)$ and the central issue of greatness which combines leadership and servanthood (Lull, 1986; Danker, 1982; Nelson, 1994). They are partly right but neglect the double meanings of $\mathrm{v} 28$. The alternation between $\dot{\varepsilon} \gamma \dot{\omega} / \hat{v} \mu \tilde{\omega} v$ in $\mathrm{v}$ $27 \mathrm{c}$ and $\dot{v} \mu \varepsilon \tilde{c} \varsigma / \dot{\varepsilon} \mu \mathrm{ov}$ in $\mathrm{v} 28$ shows that both Jesus and his disciples exercise the servanthood..$^{22}$ The literal meaning of $\delta 1 \alpha \mu \varepsilon \dot{\varepsilon} \omega$ is "remain", "accompany" or "stand by", which is one of the typical characteristics of servanthood (cf. Luke 12.35-43) (Eisenstadt and Roniger, 1984; Neyrey, 1991; Crook, 2012; Crook, 2004 ). ${ }^{23}$ The meaning of "to remain loyalty" (cf. Sirach 12.15; 22.23; 27.4; Marshall, 2009) is probably derived from the literal meaning above (Mott, 1971). ${ }^{24}$ The presence of the disciples with Jesus in his trials/suffering illustrates that service is not only related to the low status but even includes humiliation under the cross. The Lukan kai, at the beginning of v 29 indicates that in response to the service of the disciples Jesus will confer kingship on them

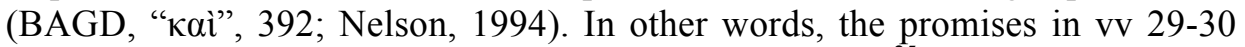
are to be offered in return for the apostles' loyalty in $\mathrm{v} 28 .^{25}$

The logical connection between the conferral of kingship ( $v 29$ ) and the privilege of disciples ( $\mathrm{v} 30$ ), or between the banquet at Jesus' table (v 30a) and judging the twelve tribes ( $\mathrm{v} 30 \mathrm{~b})$ is highly debated in scholarship. ${ }^{26}$ No matter

22 Garland (2012) claims that the statement in v 28 is more hortatory than declarative. However, considering the hard time the disciples were having in being with Jesus, it is not totally hortatory.

23 Although loyalty is also the expression of clients given to the patron, or beneficiaries to the benefactor, and loyalty to a patron or benefactor results (ideally) in benefactions being bestowed, the patron-client relationship or benefaction between Jesus and disciples is not main concern of this episode.

24 Nelson (1994) argues that such loyalty shows the perseverance in an ethical discipleship. However, there is little evidence to support the theme of discipleship in this episode.

25 Nelson (1994) and Garland (2012) hold a similar opinion.

26 Several scholars discuss $\kappa \alpha \theta \dot{\omega} \varsigma$, ǐv $\alpha$ and the relationship between the action of Jesus and of the Father, such as whether it is a comparative or consecutive connection. For example, Lagrange (1948) and Nelson (1994) regard the Father's conferral as the ground of Jesus' action. Leaney (1958) views the table as the forerunner or type of the table at the Messianic Banquet which is to inaugurate the kingdom. Nelson (1994) proposed that placing $\mathrm{v}$ 30 a after v 29 would correct an inflated idea of the apostle's authority. Besides, several scholars (eg. Schneider, 1977) focus on the conferral of the kingdom or the messianic banquet in itself such as in the eschatological age

William Loader, Boris Repschinski, Eric Wong (Eds.)

Matthew, Paul, and Others: Asian Perspectives on New Testament Themes

(C) 2019 innsbruck university press, ISBN 978-3-903187-66-5, DOI 10.15203/3187-66-5 
which solution is proposed, it usually could not cover the explanations of the two connections at the same time. It is much more reasonable to understand it from the perspectives of the dining imagery and honor-authority theme. For $\mathrm{v}$

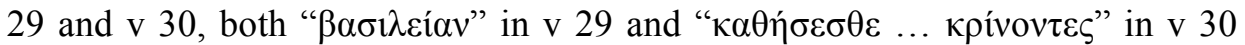
are the exercise of authority. $27 \Delta 1 \alpha \tau i \theta \eta \mu$ occurs twice and indicates that the authority of the disciples is subordinate and given from above. And the causal

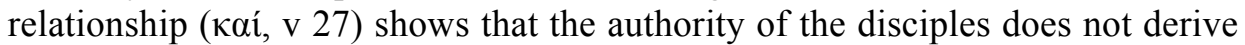
from themselves (Danker, 1987; Malina, 1988). ${ }^{28}$ What is more, the present tense of $\delta 1 \alpha \tau i \theta \varepsilon \mu \alpha$ implies that such authority is given to the disciples during Jesus' speech, but the subjunctive $\operatorname{mood}(\dddot{\varepsilon} \sigma \theta \eta \tau \varepsilon, \pi i v \eta \tau \varepsilon)$ and future tense ( $\kappa \theta \theta \dot{\sigma} \sigma \varepsilon \sigma \theta \varepsilon)$ show that this authority, while hidden in this age will be fulfilled in the coming age. ${ }^{29}$ As for $v 30 \mathrm{a}$ and $30 \mathrm{~b}$, table and throne are as close to each other as are honor and power (cf. Rev 3:20-31; Isa 65:11-14). For example, the Hellenistic monarchs of the later fourth century BCE were interested in displaying royal status and generosity especially through luxurious banquets (Athenaeus, Sophists at Dinner 7.321c-d; Donahue, 2004). No wonder the Lukan Jesus uses the banquet motif (v 27) and kingdom/judgement (v 29) motif

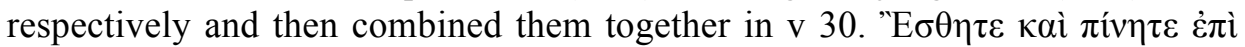

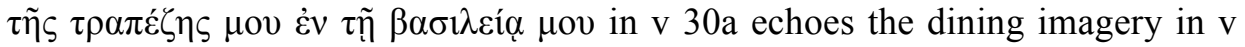
27. The contrast between serving on earth and being served (being a diner) in heaven implies that being served in heaven, which is much more honorable than

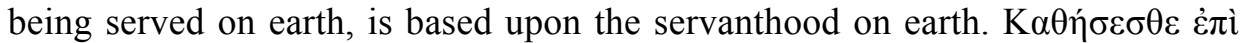

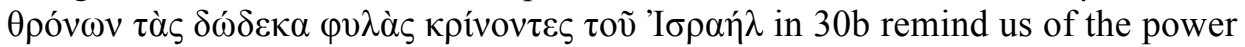
in $\mathrm{v} 25$. As an ultimate and eternal authority, the privilege and power of this authority surpass greatly any secular authority in Greco-Roman society.

In all, vv 28-30 continue the topic of honor-authority. It is not the misuse of authority, ${ }^{30}$ but the understanding of honor-authority itself that Jesus clarifies.

\footnotetext{
or the church era, which has nothing to do with the dispute of the greatest. Hence we will not discuss them here.

27 Bovon (2012) claims that the service will grant disciples access to the kingdom. However, it is not only the access to kingdom, but also judging the twelve tribes of Israel, that is, the authority to rule and judge, that is conferred on them. By comparison, more radically, Nelson (1994) proposes the conferral of the kingship to the

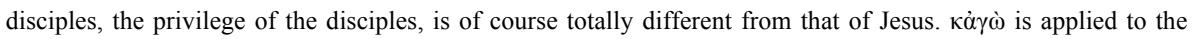
conferral behavior from up to down.

28 In v 29, it seems that the Twelve were brokers as "delegate benefactors", and Jesus is a broker through whom God acts as a benefactor-patron. Since it is not the focus of this article, we will not elaborate this further.

29 Nelson (1994) noticed this difference in tense, but he does not elaborate it.

30 Some scholars see behind vv 25-27 a problem involving the misuse of authority in the Lukan community (Horn,
}

William Loader, Boris Repschinski, Eric Wong (Eds.)

Matthew, Paul, and Others: Asian Perspectives on New Testament Themes

(C) 2019 innsbruck university press, ISBN 978-3-903187-66-5, DOI 10.15203/3187-66-5 
Vv 28-30 proposes real honor and authority. The greatest among the disciples do own some kind of honor and authority. However, instead of the manifested honor and authority in the present age, the honor and authority of the greatest are hidden in the present age and will be exercised in the future (eschatological banquet and judgment). Other than being something to be pursued, the honor and authority are given by the divine lord as the return for the service (loyalty). That is, the humble and humiliate service of the disciples makes them greatest, gaining the honor of being served and the authority of exercising judgment in heaven.

\section{Conclusion}
$\mathrm{v} 24$
dispute
v 25-26
A
negative
example
(conventional) + positive
example (uncustomary)
$\begin{array}{ll}\text { v } 27-28 & \text { B } \\ \text { v } 29-30 & \text { A }^{\prime}\end{array}$
key thesis: apparent honor and authority
negative example (conventional)+positive example (uncustomary)
B' key thesis: hidden honor and authority

The alternating of the personal pronouns "you" and "I" (v 26 "you" and v 27 "I", then v 28 "you", v 29 "I" and v 30 "you") affirms that the key point here is not to replace the Roman emperor with Jesus as the greatest and best benefactor (Seo, 2015; Danker, 1998), ${ }^{31}$ or criticize the tyrants and their tyranny (Danker, 1982), but general guidance about what it means to be the greatest for his disciples to follow. When certain scholars propose authority or power as the main topic on the basis of something other than the benefactor model or the patron-client system, they deviate from the focus of the dispute on the greatest. ${ }^{32}$ Besides, they neglect several sub-themes proposed by scholars which

1983; Schweizer, 1984; Talbert, 1982).

31 Some scholars claim that Luke heightens Jesus' authority in comparison with that of the emperor. However, since the title "benefactor" is not restricted to the emperor and Jesus does not mention his own authority in the immediate context, the comparison between Jesus' authority and emperor's is not in focus here.

32 For example, Nelson (1994) demonstrates leadership and discipleship, while it is apparent that the leadership (authority) is not applied to all disciples. Thus discipleship shall not be the focus here (Marshall, 2009; Lull, 1986).

William Loader, Boris Repschinski, Eric Wong (Eds.)

Matthew, Paul, and Others: Asian Perspectives on New Testament Themes

(C) 2019 innsbruck university press, ISBN 978-3-903187-66-5, DOI 10.15203/3187-66-5 
have nothing to do with the main topic they propose, such as the symbolism of Jesus' death and resurrection in vv 24-30 or the hope in vv 28-30.

The Lukan Jesus uses kings and benefactors as conventional examples of the greatest in political and civil realm respectively and draws attention to typical thinking in the Mediterranean world about the greatest: the greatest are those who enjoy and acquire honor, and who master or exercise dominant power over the others. The Lukan Jesus replaces this understanding one with a model which sees the youngest and the one serving, usually acknowledged as of low status and powerlessness, thus undermining the notion of greatness as reflecting superior status and dominating authority. With the banquet motif, Jesus takes the reclining diner and servant in the banquet setting as negative and positive examples respectively, to give a stern correction of the apostles' misguided understanding of honor and authority. In contrast to kings and benefactors, the disciples are to enjoy honor and exercise authority from the position of a servant. Therefore, honor is not to be pursued or given by the subjects/recipients, and authority is not derived from themselves but endowed by God. What is more, this honor and authority are hidden in this age and does not manifest until in the heavenly kingdom. To conclude, Lukan Jesus calls for a radical and drastic departure from the honor-authority model of greatness in Roman society and gives a new definition: the greatest are those of low status who give humble service (not the honorable and authoritative) on earth; their honor and authority are bestowed from God (not from the subordinates or themselves) and will be manifested in the age to come (not in this age).

\section{Bibliography}

Ahn, Yong Sung. (2006). The Reign of God and Rome in Luke's Passion Narrative: An East Asian Global Perspective. Leiden: Brill.

Bailey, J. A. (1963). The Traditions Common to the Gospel of Luke and John. Leiden: Brill.

Bovon, Francois. (2012). Luke 3 (19:28-24:53). trans. James Crouch. Minneapolis, MN: Fortress.

Crook, Zeba A. (2004). BTB Readers Guide: Loyalty. Biblical Theology Bulletin (34), 167-177.

William Loader, Boris Repschinski, Eric Wong (Eds.)

Matthew, Paul, and Others: Asian Perspectives on New Testament Themes

(C) 2019 innsbruck university press, ISBN 978-3-903187-66-5, DOI 10.15203/3187-66-5 
-----. (2012). Reconceptualising Conversion: Patronage, Loyalty, and Conversion in the Religions of the Ancient Mediterranean. Tübingen: Mohr Siebeck.

Danker, Frederick W. (1982). Benefactor: Epigraphic Study of a Graeco-Roman and New Testament Semantic Field. St Louis: Clayton.

-----. (1988). Jesus and the New Age: A Commentary on St. Luke's Gospel. Philadelphia: Fortress.

Daniel-Hughes, Carly. (2012). Bodies in Motion, Bodies at Rest. In Dennis E. Smith and Hal E. Taussig (Eds). Meals in the Early Christian World (pp. 215-227). New York, NY: Palgrave.

Deissmann, Adolf. (1927). Light from the Ancient East: The New Testament Illustrated by Recently Discovered Texts of the Greco-Roman World. London: Hodder \& Stoughton.

Dio Chrysostom, Oratio.

Donahue, J. F. (2004). The Roman Community at Table during the Principate. Ann Arbor, MI: University of Michigan.

Donahue, John F. (2015). Food and Drink in Antiquity. London: Bloomsbury.

Dunbabin, Katherine M. (2010). The Roman Banquet: Images of Conviviality. Cambridge, MA.: Cambridge University.

de Silva, D. A. (2000). Honor, Patronage, Kingship and Purity: Unlocking New Testament Culture. Downers Grove, IL: Inter-Varsity.

Dunbabin, Katherine M.D. (1998). Ut Graeco More Biberetur: Greeks and Romans on the Dining Couch. in Inge Nielsen and Hanne Sigismund Nielsen (Eds). Meals in a Social Context (pp. 81-101). Aarhus: Aarhus University.

Eilers, Claude. (2002). Roman Patrons of Greek Cities. Oxford: Oxford University.

Eisenstadt, S. N. and Roniger, L. (1984). Patrons, Clients and Friends: Interpersonal Relations and the Structure of Trust in Society. Cambridge: Cambridge University.

Esler, Philip F (Ed). (1995). Modelling Early Christianity: Social-scientific of the New Testament in its Context. London and New York: Routledge.

Fitzmyer, Joseph. (1981-1985). The Gospel according to Luke. Garden City, NY: Doubleday.

Garland, David E. (2012). Luke. Grand Rapids, MI: Zondervan. 
Gundry, Robert H. (1982). Matthew. Grand Rapids: Eerdmans.

Hendricksen, William. (1987). The Gospel of Luke. Edinburgh: Banner of Truth.

Hoebel, E. Adamson. (1958). Authority in Primitive Societies. In Carl J. Friedrich (Ed). Authority (pp. 222-234). Cambridge, Mass: Harvard University.

Horn, Friedrich W. (1983). Glaube und Handeln in der Theologie des Lukas. Göttingen: Vandenhoeck und Ruprecht.

Klinghardt, Matthias. (2012). A Typology of the Communal Meal. In Dennis E. Smith and Hal E. Taussig (Eds). Meals in the Early Christian World (pp. 9-22). New York, NY: Palgrave.

Kloppenborg, John S. (2016) Precedence at the Communal Meal in Corinth. Novum Testamentum (58), 167-203.

Leaney, A. R. C. (1958). A Commentary on the Gospel according to St. Luke. London: A. \& C. Black.

Lucian, Dialogues of the Courtesans.

Lull, David J. (1986). the Servant-Benefactor as a Model of Greatness (Luke 22:24-30). Novum Testamentum (28), 289-305.

Jeremias, J. (1963). New Testament Theology (vol. 1). tans. John Bowden. London: SCM.

Malina, Bruce J. (1988). Patron and Client: The Analogy Behind Synoptic Theology. Forum (4), 2-32.

Marshall, Jonathan (2009). Jesus, Patrons, and Benefactors. Tübingen: Mohr Siebeck.

McRae, Rachel M. (2011). Eating with Honor: The Corinthian Lord' Supper in Light of Voluntary Association Meal Practices. Journal of Biblical Literature (130), 165-181;

Moxnes, Halvor. (1991). Patron-Client Relations and the New Community in LukeActs. In Jerome H. Neyrey (Ed). The Social World of Luke-Acts (pp. 241268). Peabody, MA: Hendrickson.

Morris, Leon. (1988). The Gospel according to Luke. London: Inter-Varsity.

Mott, S. C. (1971) The Greek Benefactor and Deliverance from Moral Distress. PhD diss. Harvard University.

Nelson, Peter K. (1994). Leadership and Discipleship: A Study of Luke 22:24-30. Atlanta, Ga.: Scholars.

William Loader, Boris Repschinski, Eric Wong (Eds.)

Matthew, Paul, and Others: Asian Perspectives on New Testament Themes

(C) 2019 innsbruck university press, ISBN 978-3-903187-66-5, DOI 10.15203/3187-66-5 
Neyrey, Jerome H. (1991). Ceremonies in Luke-Acts: The Case of Meals and Table Fellowship. In Jerome H. Neyrey (Ed). The Social World of Luke-Acts (361387). Peabody, MA: Hendrickson.

Nicols, John. (1990). Patrons of Greek Cities in the Early Principate. ZPE (80), 81-108.

Nock, Arthur D. (1972). Soter and Euergetes. In Zeph Stewart (Ed). Essays on Religion and the Ancient World (pp. 720-735). vol. 2. Oxford: Clarendon.

Nolland, John. (1989-1993). Luke. Dallas, TX: Word.

Petronius, Satyricon.

Pitt-Rivers, Julian. (1977). The Fate of Shechem or the Politics of Sex: Essays in the Anthropology of the Mediterranean. Cambridge: Cambridge University.

Philo, Cont.

Pliny, Natural History.

Plutarch, Life of Pompey.

Plummer, Alfred. (1901). The Gospel according to St. Luke. Edinburgh: Clark.

Augustus. Res Gestae Divi Augustus

Roller, Matthew. (2006). Dining Posture in Ancient Rome. Princeton, N.J.: Princeton University.

Saller, Richard. (1982). Personal Patronage under the Early Empire. Cambridge: Cambridge University.

Schneider, G. (1977). Das Evangelium nach Lukase. Gütersloh: Mohn.

Schürmann, H. (1957). Jesu Abschiedsrede, Lk 22, 21-38. Munster: Aschendorff.

Schweizer, Eduard. (1984). The Good News according to Luke. David E. Green (Trans). Atlanta: John Knox.

Seager, Robin. (2002). Pompey the Great. Malden, MA: Blackwell.

Seneca, de Beneficiis.

Seo, Pyung Soo. (2015). Luke's Jesus in the Roman Empire and the Emperor in the Gospel of Luke. Eugene, Oregon: Pickwick.

Smith, Dennis E. (2012). The Greco-Roman Banquet as a Social Institution. In Dennis E. Smith and Hal E. Taussig (Eds). Meals in the Early Christian World (pp. 2336). New York, NY: Palgrave. 
Southern, Pat. (2002). Pompey the Great. Stroud: Tempus.

Suetonius, Poet. fr.

Talbert, Charles. H. (1982). Reading Luke: A Literary and Theological Commentary on the Third Gospel. New York: Crossroad.

Taylor, Vicent. (1975). The Passion Narrative of St. Luke. Cambridge: Cambridge University.

van Wees, Hans. (1998). The Law of Gratitude: Reciprocity in Anthropological Theory. In C. Gill, N. Postlethwait and R. Seaford (Eds). Reciprocity in Ancient Greece (pp. 13-50). New York: Oxford University.

Winter, B. (1988). The Public Honouring of Christian Benefactions. Romans 13.3-4 and 1 Peter 2.14-15. JSNT (34), 87-103. 